\title{
DIAGNOSIS KEGAGALAN CHILLER MENGGUNAKAN ANALISIS PARAMETER OPERASI
}

\section{CHILLER FAULTSDIAGNOSIS USING OPERATING PARAMETER ANALISYS}

\author{
Nofirman Firdaus ${ }^{a}$, Bambang Teguh Prasetyo ${ }^{b}$, Yusuf Rasyid ${ }^{a}$, Maha Hidayatullah ${ }^{a}$ \\ aJurusan Teknik Mesin Sekolah Tinggi Teknik PLN, Jakarta \\ 'BT2MP-BPPT, Gedung 230, Puspiptek, Serpong, Tangerang Selatan \\ e-mail: nofirman@sttpln.ac.id, bambang.teguh@bppt.go.id, \\ yusufrasyid@gmail.com, mahaakbar96@gmail.com
}

\begin{abstract}
Abstrak
Penelitian ini bertujuan untuk melakukan identifikasi kegagalan pada chiller berdasarkan analisis parameter operasi kunci untuk masing-masing jenis kegagalan dengan menggunakan model regresi satu variable. Satu variabel tersebut adalah beban pendinginan (EvapTons) saja. Hasil tersebut dibandingkan dengan penelitian yang dilakukan peneliti sebelumnya dengan model regresi tiga variable yaitu temperatur air keluar evaporator (TEO), temperatur air masuk kondebsor (TCl) dan EvapTons. Hasil perbandingan berdasarkan kecenderungan perubahan parameter operasi menunjukkan bawah diagnosa kegagalan bisa dilakukan cukup tepat (sekitar 93\%) dengan menggunakan parameter operasi yang dihasilkan dari model regresi satu variable.Dari 29 skenario kegagalan, 27 skenario kegagalan dapat diidentifikasi dengan model regresi satu variabel.
\end{abstract}

Kata kunci:Diagnosa kegagalan chiller, chiller FDD

\begin{abstract}
Abstrack
This entry is intended to identify chiller faults based on key operating parameter analysis for each type of faults using one variable regression model. One such variable is the cooling load (EvapTons). The result is compared with previous research that used three variables regression model; the outlet evaporator water temperature (TEO), the inlet condenser water temperature $(\mathrm{TCl})$ and EvapTons. The result of comparison based on the change in the trend of operating parameter shows that the fault diagnosis can be performed properly (around 93\%) using operating parameter generated from one variable regression model.Result from 29 fault scenarios, 27 fault scenarios can be identified by the one-variable regression model.
\end{abstract}

Keyword:Chiller faults diagnosis, chiller FDD

Diterima (received ) : 11 Mei 2018, Direvisi (revised ) : 11 Juli 2018

Disetujui (accepted) : 16 Juli 2018 


\section{PENDAHULUAN}

Chiller merupakan sumber konsumsi energi terbesar padakebanyakan gedung komersial. Besarnya enegi listrik yang dikonsumsi mencapai sekitar $40-50 \%$ dari total energy yang digunakan ${ }^{(1,} \quad 9$ ). Sebagaimana peralatan lainnya, semakin lama chiller beroperasi maka kinerja chiller akan menurun, yang akibatnya chiller membutuhkan energi lebih banyak untuk menghasilkan beban pendinginan yang sama. Perbaikan kinerja akan menghasilkan penghematan energi yang cukup besar. Salah satu cara untuk mengembalikan kinerja adalah dengan tindakan pemeliharaan. Pemeliharaan yang tepat dalam jangka panjang dapat mengurangi atau mengendalikan konsumsi energi chiller'). Hal ini dibenarkan bila kita mengetahui apa yang harus dipelihara dan kapan melakukannya.

Terdapat banyak jenis kegagalan yang dapat terjadi pada chiller baik yang terjadi pada sistem elektrikal, instrumentasi, sisi air dan refrigeran, pada alat bantu, dan lain sebagainya. Comstock telah melakukan surveikegagalan pada chiller berdasarkan data histori kegagalan yang diperoleh dari beberapa manufaktur chiller di Amerika Serikat ${ }^{(3)}$. Penelitian tersebut bertujuan untuk memetakan jenis kegagalan yang paling sering terjadi, dan juga besarnya biaya relatif -yang dibutuhkan untuk perbaikan masingmasing jenis kegagalan tersebut.

Berdasarkan hasil surveiyang pernah dilakukan tersebut, kegagalan yang terjadi dibagi ke dalam dua kategori. Pertama adalah kegagalan "keras" (hard failure) dan yang kedua adalah kegagalan "halus" (soft failure)(4). Kegagalan jenis hard failure ini lebih mudah terdeteksi karena chiller berhenti beroperasi atau hilangnya kemampuan untuk menghasilkan air dingin (chilled water). Contoh hard failureadalah kerusakan pada kompresor yang berujung pada habisnya refrigeran didalam sistem ${ }^{(4)}$, dan rusaknya atau terbakarnya motor listrik penggerak kompresor. Sedangkan soft failure lebih sulit dideteksi karena chiller masih terus beroperasi tetapi hanya terjadi degradasi kinerjanya $^{(4)}$. Contoh soft failure ini adalah kehilangan refrigeran dalam jangka panjang yang terjadi secara perlahan, dan fouling yang terjadi pada kondensor.

Berdasarkan surveikegagalan yang dilakukan, Comstock kemudian menyeleksi kembali kegagalan soft failureyang ada pada surveitadi menjadi delapan jenis kegagalan yang sangat berpengaruh terhadap kinerja chiller. Delapan jenis kegagalan ini bisa dilihat pada Tabel 1.
Kemudian Comstock melakukan kajian eksperimental untuk delapan jenis kegagalan ini pada chiller kapasitas 90 Ton Refrigeration $(\mathrm{TR})^{(5)}$. Data hasil eksperimental yang diperoleh digunakan sebagai bank data dalam mengembangkan dan menvalidasi metode untuk mendeteksi dan mendiagnosa kegagalan pada chiller, yang dikenal dengan istilah failure detection and diagnostic (FDD).

Tabel 1.

Jenis kegagalan yang umum terjadi5,6)

\begin{tabular}{cl}
\hline No & \multicolumn{1}{c}{ Jenis Kegagalan } \\
\hline 1 & Berkurangnya air kondensor \\
2 & Berkurangnya air evaporator \\
3 & Kebocoran refrigeran \\
4 & Refrigeran berlebihan \\
5 & Minyak pelumas berlebihan \\
6 & Fouling pada kondensor \\
7 & Non-condensable gas (NCG) \\
8 & Kerusakan katup ekspansi \\
\hline
\end{tabular}

Data eksperimental ini telah banyak digunakan oleh para peneliti dalam pengembangan metode FDD.Dari data eksperimental yang diperoleh(5), Comstock melakukan uji kesensitifan dari parameterparameter operasi chiller yang berjumlah 13 (tiga belas) parameter. Tiga belas parameter tersebut adalah daya kompressor (kW), tekanan evaporator (PRE), tekanan kondensor (PRC), temperatur subcooling kondensor (TRC), temperatur superheat masuk kompresor (Tsh $\mathrm{suc}_{\text {sc }}$, temperatur superheat keluar kompressor (Tsh dis), temperatur approach evaporator (TEA) dan kondensor (TCA), perbedaan temperatur air kondensor (TCO-TCI) dan evaporator (TEITEO), kinerja chiller (kW/Ton), temperatur oli (TO), dan temperatur oli masuk ( $\mathrm{TO}_{\text {feed }}$ ), seperti pada Tabel 2. Parameter ini di evaluasi dengan menggunakan regresi tiga variabel seperti pada persamaan (1). Tiga variabel yang digunakan sebagai input regresi tersebut adalah temperatur air keluar evaporator (TEO), temperatur air masuk kondensor $(\mathrm{TCl})$, dan beban evaporator dalam Ton Refrigeration (TR) yang selanjutnya disebut EvapTons. Sedangkan y adalah parameter operasi yang ingin dicari. Parameter operasi yang dicari dengan persamaan (1) bisa dilihat di Tabel 2 . Penjelasan lokasi pengukuran TEO, TCl, dan lain-lain bisa dilihat di Gambar 1 .

$$
\begin{gathered}
y=a_{0}+a_{1} \cdot \text { TEO }+a_{2} \cdot \text { TCl }+a_{3} \text {.EvapTons }+ \\
a_{4} \text {. TEO.EvapTons }+a_{5} \text {. TCl.EvapTons }+ \\
a_{6} \text { EvapTons }^{2}
\end{gathered}
$$


Kemudian dengan input tiga variabel tersebut, regresi untuk mencari variabel y dapat dilakukan. Hasil dari regresi digunakan untuk melihat pengaruh masing-masing parameter operasi terhadap masing-masing jenis kegagalan dan tingkat keparahan kegagalan.

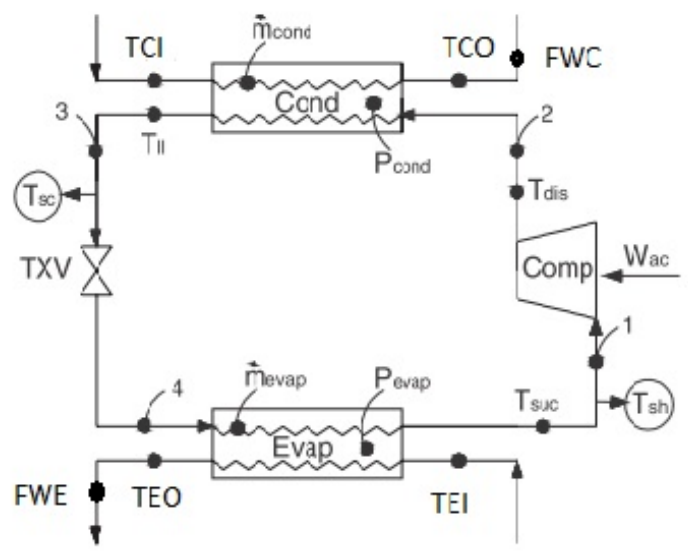

Gambar 1.

Posisi Alat Ukur pada Sistem Chiller

Untuk masing-masing jenis kegagalan, dari hasil regresi persamaan (1), dihitung ulang berdasarkan konstanta yang didapat dari proses regresi tersebut. Kemudian dibuatlah grafik (Gambar2) dengan input temperatur air keluar evaporator (TEO) pada suhu $45^{\circ} \mathrm{F}\left(7,22^{\circ} \mathrm{C}\right)$, temperatur air masuk kondensor $(\mathrm{TCl})$ sebesar $65^{\circ} \mathrm{F}\left(18,33^{\circ} \mathrm{C}\right)$ untuk kegagalan level 1,2,3 dan 4, dimana beban evaporator (EvapTons) ditentukan berdasarkan data yang ada. Kemudian dengan cara yang sama dilakukan dengan memvariasikan $\mathrm{TCl}$ pada $75^{\circ} \mathrm{F}$ dan $85^{\circ} \mathrm{F}$ sedangkan TCO tetap. Dari hasil ini dibuatlah grafik pada penelitian terdahulu(6) (pengaruh masing-masing jenis kegagalan terhadap 13 parameter operasi. Untuk pengaruh berkurangnya debit air kondensor terhadap perbedaan temperatur air kondensor (TCOTCI) bisa dilihat pada Gambar 2 dengan TEO konstan dan $\mathrm{TCl}$ bervariasi.

Kecenderungan yang terjadi untuk masing-masing parameter operasi akibat masing-masing jenis kegagalan yang dialami, divisualisasikan dengan tanda panah (Tabel 2). Tanda panah berjumlah 1,2, dan 3 buah menggambarkan kecenderungan kenaikan persentase dari masing-masing parameter operasi. Sedangkan simbol titik (.)menunjukkan tidak ada perubahan persentase yang berarti (relatif konstan). Dari hasil inilah kemudian Comstock membuat pedoman untuk aplikasi ruled-based diagnostician (RBD)di Tabel $2^{(6)}$.

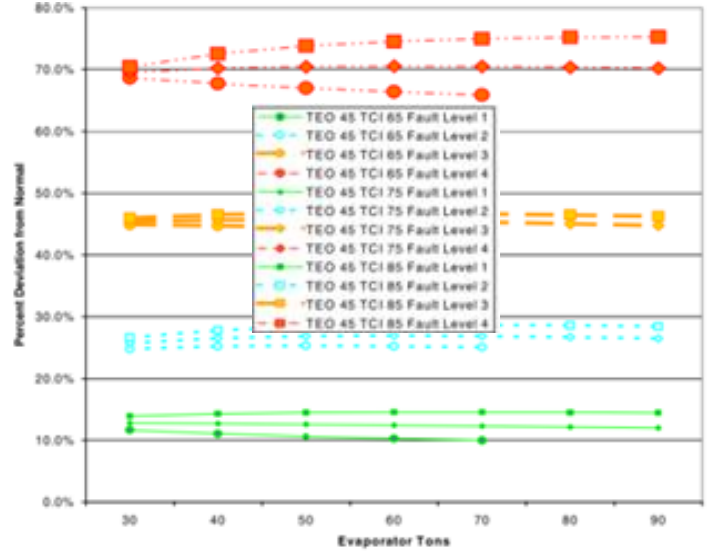

Gambar 2.

Deviasi Perbedaan Temperatur Air Kondensor Akibat Berkurangnya Debit Air Kondensor ${ }^{(6)}$.

Untuk aplikasi lapangan, metode dengan regresi tiga variabel ini memiliki "kekurangan" yaitu; pertama, nilai TEO dan $\mathrm{TCl}$ telah ditentukan sebelumnya, bukan berasal dari data operasi riil seperti pada Gambar 2. Sedangkan nilai TEO dan TCI dalam keadaan sesungguhnya sangat bervariasi. Kedua, metode regresi tiga variabel ini juga berpotensi sulit untuk diaplikasikan khususnya untuk analissis yang dilakukan secara manual, hal ini karena pada umumnya para operator atau pengguna chiller berlatar pendidikan SMK ${ }^{(2)}$. Sedangkan "kelebihan" metode regresi tiga variabel ini dapat memprediksi nilai masing-masing parameter operasi lebih akurat berdasarkan nilai $R^{2}$ (coefficient of determination) yang diperoleh (lihat Tabel 14).

Tabel 2.

Pedoman untuk aplikasi RBD $(4,6)$

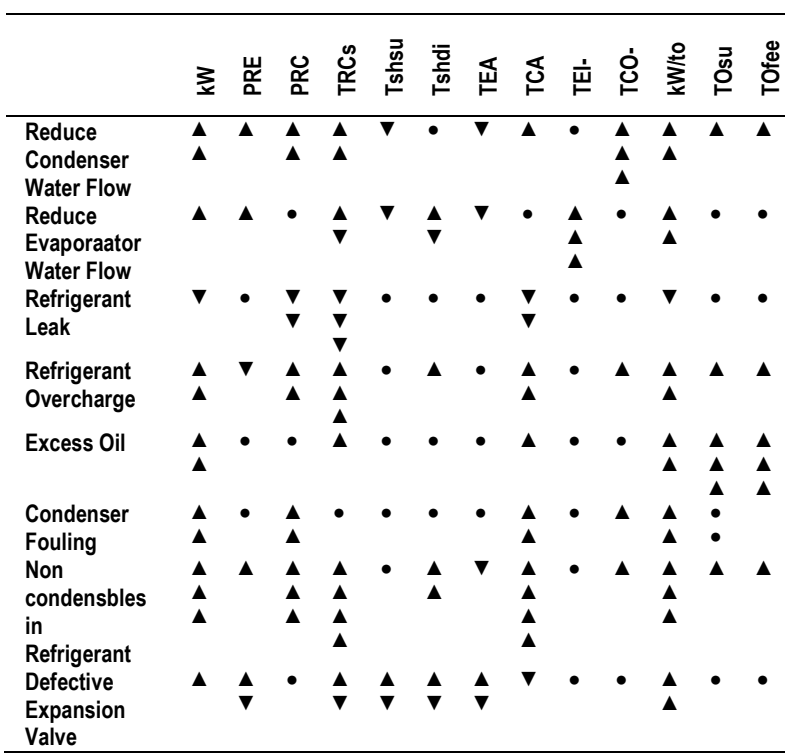


Dengan prtimbangan kekurangan di atas, maka perlu dilakukan analisa penggunaan RBD ini dengan mengaplikasikan metode regresi satu variabel.Metode ini lebih sederhana dan mudah diajarkan kepada operator/pengguna chiller. Penelitian ini bertujuan untuk mengaplikasikan analisa model regresi satu variabel dengan menggunakan data eksperimental yang sama sebagaimana yang dilakukan oleh Comstock dalam penelitiannya.

\section{METODE}

Langkah awal yang dilakukan dalam penelitian ini adalah menyederhanakan jumlah parameter operasi chiller untuk masing-masing kegagalan. Hanya parameter operasi yang dianggap berpengaruh besar terhadap diagnosa kegagalan yang akan dilakukan pengolahan dan analisa data. Sehingga jumlah parameter operasi yang digunakan berkurang dari 13 parameter operasi.

Dari data eksperimental yang dihasilkan Comstock(5) akan difilter berdasarkan kesetimbangan energi yang terjadi pada sistem, variasi yang terjadi tidak lebih dari $5 \%$. Hal ini dilakukan oleh Jayaprakash ${ }^{(7)}$ dalam menggunakan data eksperimental Comstock untuk menguji metode FDD simple thermodynamics model (STM) sebagai FDD pada chiller. Langkah berikutnya akan dilakukan analisa regresi satu variabel persamaan (2) yang relatif lebih sederhana dibandingkan regresi tiga variabel pada persamaan (1). Regresi dilakukan untuk data kondisi normal dan data untuk masingmasing jenis dan level kegagalan. Parameter yang dicari dari persamaan (2) adalah parameter operasi yang dianggap mewakili untuk melakukan diagnosa kegagalan yang terjadi.

$$
\mathrm{y}=\mathrm{a}_{0}+\mathrm{a}_{1} . \text { EvapTons }+\mathrm{a}_{2} . \text { EvapTons }^{2}
$$

Untuk perhitungan pers (2) dengan menggunakan Microsoft Excel bisa dilakukan dengan cara sebagai berikut:

1. Misalkan "y" adalah perbedaan temperatur air kondensor (TCO-TCI)

2. Gunakan nilai beban evaporator (EvapTons) yang ada pada data eksperimental comstock $^{(5)}$ untuk jenis kegagalan berkurangnya air kondensor.

3. Kemudian gunakan aplikasi "Data" yang terdapat pada Excel dan pilih "Data analysis".
4. Dari "analysis tool" pilih "regression".

5. Masukkan data (TCO-TCl) ke dalam "input y range"

6. Masukkan data "EvapTons" dan "EvapTons^2" kedalam "input x range"

Hasil regresi dari pers (2) akan diperoleh nilai konstanta $a_{0}, a_{1}$, dan $a_{2}$ untuk regresi satu variabel akan di lembar kerja Excel. Dengan diketahui konstanta maka dapat dibuat grafiknya seperti terlihat pada Gambar.3.

Sebagai contoh; dimisalkan pada parameter perbedaan temperatur air kondensor (TCO TCI) untuk kegagalan level 1. Dimana diperoleh konstanta $a_{0}=2,1144, a_{1}=-0,0335$, dan $\mathrm{a}_{2}=0,0002$. Nilai korelasi $\mathrm{R}=0,9686$ dan nilai koefisien determinasi $\mathrm{R}^{2}=0,9382$.

Tabel 3.

Kondisi normal dan level kegagalan (5)

\begin{tabular}{|c|c|c|c|c|c|c|}
\hline \multirow[b]{2}{*}{ No } & \multirow{2}{*}{$\begin{array}{c}\text { Jenis } \\
\text { Kegagalan }\end{array}$} & \multirow[b]{2}{*}{ Normal } & \multicolumn{4}{|c|}{ Kegagalan, \%) } \\
\hline & & & $\begin{array}{c}\text { Level } \\
1\end{array}$ & $\begin{array}{l}\text { Level } \\
2\end{array}$ & $\begin{array}{c}\text { Level } \\
3\end{array}$ & $\begin{array}{c}\text { Level } \\
4\end{array}$ \\
\hline 1 & $\begin{array}{l}\text { Debit air } \\
\text { kondensor } \\
\text { yang } \\
\text { berkurang }\end{array}$ & $\begin{array}{c}17,03 \\
(\mathrm{l} / \mathrm{s})\end{array}$ & -10 & -20 & -30 & -40 \\
\hline 2 & $\begin{array}{l}\text { Debit air } \\
\text { evaporator } \\
\text { yang } \\
\text { berkurang }\end{array}$ & $\begin{array}{c}13,63 \\
(\mathrm{I} / \mathrm{s})\end{array}$ & -10 & -20 & -30 & -40 \\
\hline 3 & $\begin{array}{l}\text { Kebocoran } \\
\text { refrigerant }\end{array}$ & $30 \mathrm{lbs}$ & -10 & -20 & -30 & -40 \\
\hline 4 & $\begin{array}{l}\text { Kapasita } \\
\text { refrigerant } \\
\text { berlebihan }\end{array}$ & $30 \mathrm{lbs}$ & 10 & 20 & 30 & 40 \\
\hline 5 & $\begin{array}{l}\text { Pelumas } \\
\text { kompresor } \\
\text { berlebih }\end{array}$ & $0.17 \mathrm{~kg}$ & 14 & 32 & 50 & 68 \\
\hline 6 & $\begin{array}{l}\text { Fouling pada } \\
\text { kondensor }\end{array}$ & 164 ріра & -12 & -20 & -30 & -45 \\
\hline 7 & $\begin{array}{l}\text { Non- } \\
\text { condensable } \\
\text { gas }\end{array}$ & $\begin{array}{c}0 \% \\
\text { nitrogen }\end{array}$ & 1 & 2 & 3 & 4 \\
\hline 8 & $\begin{array}{l}\text { Kerusakan } \\
\text { katup } \\
\text { ekspansi }\end{array}$ & Normal & $\mathrm{N} / \mathrm{A}$ & $\mathrm{N} / \mathrm{A}$ & $\mathrm{N} / \mathrm{A}$ & $\mathrm{N} / \mathrm{A}$ \\
\hline
\end{tabular}

Dengan cara yang sama dapat dipalikasikan pada pers (1) untuk memperoleh konstanta $a_{0}, a_{1}, a_{2}, a_{3}, a_{4}, a_{5}$, dan $a_{6}$. Hasil prediksi variabel y (parameter operasi acuan) pada kondisi normal kemudian dibandingkan dengan hasil prediksi untuk masing-masing jenis kegagalan yang terjadi untuk setiap level kegagalan. Presentase perubahan parameter operasi ditabulasi untuk tiap-tiap jenis kegagalan berdasarkan level kegagalan yang terjadi. Tingkat kegagalan dibagi menjadi empat level untuk semua jenis kegagalan kecuali kegagalan pada katup ekspansi (Tabel 3). 
Hasil tabulasi kecenderungan parameter operasi juga akan dibandingkan dengan hasil kecenderungan yang diperoleh oleh Comstock $(4,6)$

Untuk mempermudah diagnosa kegagalan yang terjadi, maka parameter yang digunakan pada Tabel.2 disederhanakan dengan hanya menggunakan parameter operasi yang bisa membedakan dengan kegagalan jenis lainnya. Hasil simplifikasi parameter operasi bisa di lihat di Tabel 4. Hasil penyederhanaan ini mengurangi jumlah parameter yang perlu dianalisa dari 13 variabel menjadi 7 variabel untuk mengidentifikasi jenis kegagalan yang mungkin terjadi.

Tabel 4

Simplifikasi parameter operasi chiller

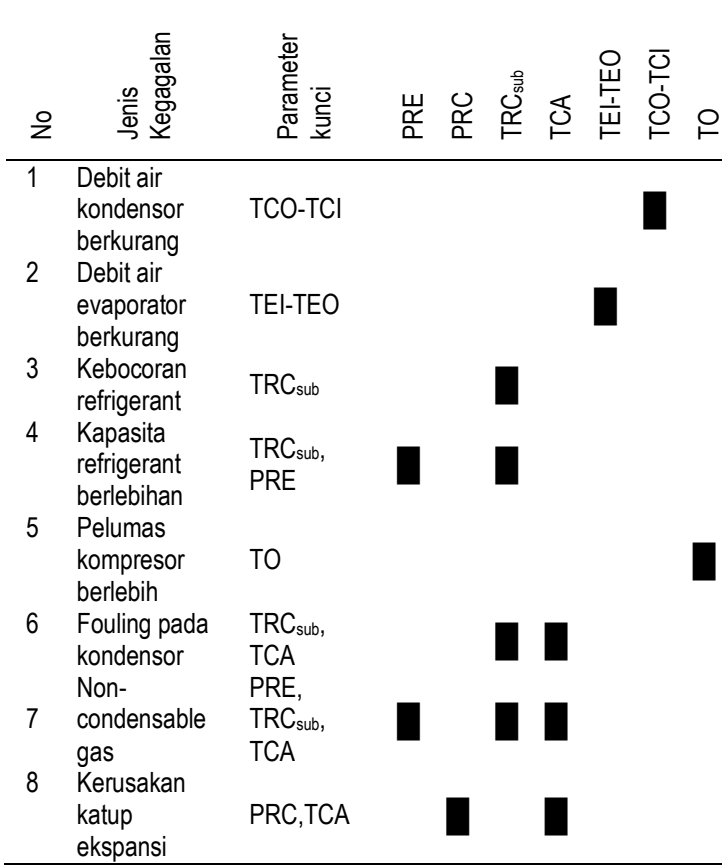

\section{HASIL DAN PEMBAHASAN}

Jika diperhatikan Tabel 2, untuk kegagalan karena berkurangnya debit air kondensor dapat dilihat dari kenaikan parameter perbedaan temperatur air kondensor (TCO-TCl) yang merupakan faktor yang paling dominan untuk jenis kegagalan ini. Akan tetapi kenaikan TCO-TCl yang rendah juga terdapat pada kegagalan yang diakibatkan oleh berkurangnya refrigerant, fouling pada kondensor, dan adanya kandungan non-condensable gas didalam sistem (Tabel 2).
Sehingga dalam hal ini, parameter TCO-TCI dapat mengidentifikasi berkurangnya debit air kondensor ketika level kegagalan yang terjadi semakin tinggi. Ditambah, tiga jenis kegagalan yang lainnya memiliki parameter kunci yang berbeda dengan jenis kegagalan berkurangnya air kondensor (Tabel 4), sehingga diagnosa akan lebih mudah dilakukan. Dikarenakan hal diatas, parameter kunci untuk mendiagnosa berkurangnya air kondensor yang akan digunakan dalam analisa adalah perbedaan temperatur air keluar dan masuk kondensor (TCO-TCl). Perbedaan temperatur air kondensor semakin besar dengan semakin berkurangnya air kondensor jika dibandingkan dengan TCO-TCI pada kondisi normal (Gambar.3). Persentasi kenaikan temperatur air kondensor dibanding dengan hasil yang diperoleh Comstock (Tabel5) memiliki sedikit perbedaan, akan tetapi memiliki kecenderungan yang sama yaitu (TCO-TCI) semakin meningkat dengan semakin berkurangnya debit air kondensor jika dibandingkan debit air pada kondisi normal.

Tabel 5.

Deviasi rata-rata (TCO-TCI) untuk debit air kondensor yang berkurang

\begin{tabular}{|c|c|c|c|c|c|}
\hline \multirow[b]{2}{*}{ No } & \multirow{2}{*}{$\begin{array}{l}\text { Debit air } \\
\text { kondensor }\end{array}$} & \multicolumn{4}{|c|}{ Level, (\%) } \\
\hline & & $\begin{array}{c}\text { Level } \\
1 \\
\end{array}$ & $\begin{array}{c}\text { Level } \\
2 \\
\end{array}$ & $\begin{array}{c}\text { Level } \\
3 \\
\end{array}$ & $\begin{array}{c}\text { Level } \\
4\end{array}$ \\
\hline 1 & (TCO-TCI) & 7,8 & 24,7 & 44,3 & 69,3 \\
\hline 2 & $\begin{array}{l}(\mathrm{TCO}-\mathrm{TCl}) \\
\text { Comstock }^{(6)}\end{array}$ & 12,4 & 26,5 & 45,3 & 70,2 \\
\hline
\end{tabular}

Oleh karena itu kenaikan TCO-TCI bisa digunakan untuk mendiagnosis berkurangnya air kondensor pada level kegagalan yang lebih tinggi (Level 2,3,dan 4).

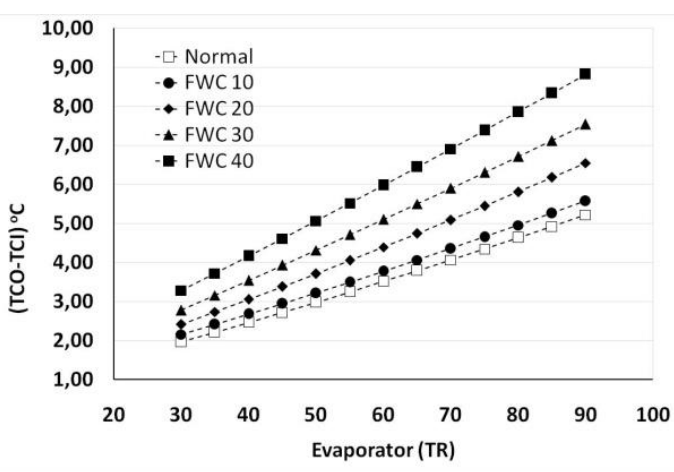

Gambar 3.

Pengaruh debit air kondensor terhadap TCO-TCl 
Tabel 6.

Deviasi rata-rata TEO-TEl untuk debit air evaporator yang berkurang

\begin{tabular}{|c|c|c|c|c|c|}
\hline \multirow[b]{2}{*}{ No } & \multirow[b]{2}{*}{$\begin{array}{l}\text { Debit air } \\
\text { evaporator }\end{array}$} & \multicolumn{4}{|c|}{ Level, (\%) } \\
\hline & & $\begin{array}{c}\text { Level } \\
1 \\
\end{array}$ & $\begin{array}{c}\text { Level } \\
2 \\
\end{array}$ & $\begin{array}{c}\text { Level } \\
3 \\
\end{array}$ & $\begin{array}{c}\text { Level } \\
4\end{array}$ \\
\hline 1 & (TEI-TEO) & 10,0 & 22,1 & 38,4 & 56,6 \\
\hline 2 & $\begin{array}{l}\text { (TEI-TEO) } \\
\text { Comstock }^{(6)}\end{array}$ & 10,2 & 22,3 & 38,8 & 55,8 \\
\hline
\end{tabular}

Indikator operasi yang digunakan untuk mendiagnosis berkurangnya air evaporator adalah perbedaan temperatur air masuk dan keluar evaporator (TEO-TEI). Dari Tabel 2 dan Gambar 4 terlihat bahwa semakin berkurang debit air evaporator maka TEO-TEI semakin besar, hasil yang sama juga diperoleh oleh Comstock (6) seperti ditunjukkan oleh Tabel 2 dan Tabel 6, dan juga kenaikan parameter TEO-TEI memiliki trend yang sama dengan hasil yang diperoleh Comstock (Tabel 6). Dari Tabel 2, indikator perubahan TEO-TEI hanya dimiliki oleh kegagalan akibat berkurangnya debit air evaporator dan tidak dimiliki oleh jenis kegagalan yang lain. Oleh karena itu, parameter TEO-TEI dapat digunakan sebagai indikator kunci untuk jenis kegagalan yang disebabkan oleh berkurangnya debit air evaporator.

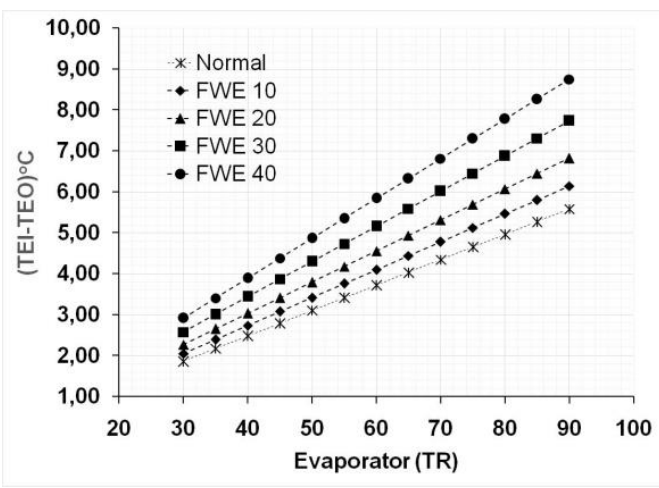

Gambar 4.

Pengaruh debit air evaporator terhadap TEO-TEI

Kebocoran refrigeran adalah kegagalan jenis ketiga yang diuji oleh Comstock $(5,6)$. Simulasi dilakukan dengan cara mengurangi kapasitas refrigeran kelipatan $10 \%$ dari kondisi normal untuk tiap level kegagalan. Pengaruh berkurangnya kapasitas refrigeran terhadap kinerja chiller (kW/Ton) menunjukkan bahwa berkurangnya refrigeran justru meningkatkan kinerja chiller yang ditandai dengan menurunnya konsumsi energi $\mathrm{kW} / T$ on untuk setiap skenario kegagalan (Tabel 7 dan Gambar 5).
Sedangkan Comstock(6) mendapati bahwa kinerja chiller rata-rata menurun pada level kegagalan 1 dan 2, dan kemudian meningkat untuk level kegagalan 3 dan 4 (Tabel 7).

Tabel 7.

Deviasi rata-rata TRC akibat kebocoran refrigeran

\begin{tabular}{|c|c|c|c|c|c|}
\hline \multirow[b]{2}{*}{ No } & \multirow{2}{*}{$\begin{array}{l}\text { Kebocoran } \\
\text { refrigerant }\end{array}$} & \multicolumn{4}{|c|}{ Level, (\%) } \\
\hline & & $\begin{array}{c}\text { Level } \\
1 \\
\end{array}$ & $\begin{array}{c}\text { Level } \\
2 \\
\end{array}$ & $\begin{array}{c}\text { Level } \\
3 \\
\end{array}$ & $\begin{array}{c}\text { Level } \\
4 \\
\end{array}$ \\
\hline 1 & TRC & $-4,9$ & $-8,6$ & $-16,1$ & $-24,1$ \\
\hline 2 & $\begin{array}{l}\text { TRC, } \\
\text { Comstock }^{(6)}\end{array}$ & 0,9 & $-4,7$ & $-35,5$ & $-66,0$ \\
\hline
\end{tabular}

Kebocoran refrigeran adalah kegagalan jenis ketiga yang diuji oleh Comstock ${ }^{(5,6)}$. Simulasi dilakukan dengan cara mengurangi kapasitas refrigeran kelipatan $10 \%$ dari kondisi normal untuk tiap level kegagalan. Berdasarkan Tabel 2 terdapat satu indikator kunci untuk mengidentifikasi kegagalan yang diakibatkan oleh berkurangnya refrigeran didalam chiller yaitu temperatur subcooling kondensor (TRC). Dalam penelitian lain, Tassou juga mendapatkan bahwa TRC merupakan variabel kunci untuk mengdiagnosa kebocoran refrigeran ${ }^{(8)}$. TRC semakin rendah dengan berkurangnya jumlah refrigeran didalam chiller (Tabel 7 dan Gambar 5), hal yang sama juga diperoleh oleh Comstock (Tabel 7) kecual untuk kegagalan level 1, dimana TRC naik sedikit. Secara kecenderungan, indikator turunnya TRC dapat digunakan untuk mendiagnosa berkurangnya jumlah refrigeran didalam chiller.

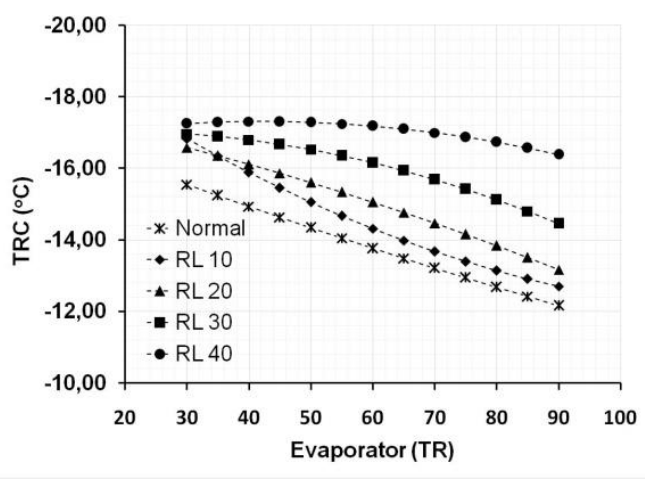

Gambar 5.

Pengaruh berkurangnya refrigeran terhadap TRC

Kegagalan berikutnya adalah kapasitas refrigeran yang berlebihan. Jenis disimulasikan dengan menambah volume refrigeran kelipatan 10\% untuk masingmasing level kegagalan. 
Untuk kegagalan jenis ini berdasarkan Tabel 2, parameter operasi yang dapat digunakan untuk mengidentifikasi kegagalan memiliki kesamaan dengan kegagalan akibat adanya kandungan non-condensable gas didalam chiller (Tabel 2) yaitu TRC, PRC dan TCA. Untuk kelebihan refrigeran, parameter yang tampak jelas adalah adanya kenaikan pada TRC. Untuk membedakan dengan jenis kegagalan akibat non-condensable gas(NCG) maka perlu ditambahkan parameter tekanan evaporator (PRE) untuk mengidentifikasi jenis kegagalan ini dengan tepat. PRE menurun pada kegagalan jenis ini, dan berbeda dengan kegagalan NCG dan kegagalan jenis lainnya dimana terdapat kenaikan PRE. Pengecualin terdapat pada kegagalan akibat katup ekspansi, dimana PRE bisa naik dan bisa turun tergantung kondisi operasi, tetapi pada kegagalan katup ekspansi nilai TRC berbeda dengan kegagalan kelebihan refrigeran. Oleh karena itu, parameter operasi yang dapat digunakan untuk mengidentifikasi kelebihan refrigeran adalah TRC dan tekanan evaporator (PRE). Baik TRC dan PRE dengan regresi satu variabel mampu mendiagnosa kapasitas refrigeran yang berlebih didalam sistem (Tabel 8 dan Gambar 6).

Tabel 8.

Deviasi rata-rata TRC dan PRE akibat refrigeran yang berlebih.

\begin{tabular}{|c|c|c|c|c|c|}
\hline \multirow[b]{2}{*}{ No } & \multirow{2}{*}{$\begin{array}{l}\text { Refrigerant } \\
\text { berlebih }\end{array}$} & \multicolumn{4}{|c|}{ Level, (\%) } \\
\hline & & $\begin{array}{c}\text { Level } \\
1 \\
\end{array}$ & $\begin{array}{c}\text { Leve } \\
12\end{array}$ & $\begin{array}{c}\text { Level } \\
3\end{array}$ & $\begin{array}{c}\text { Level } \\
4\end{array}$ \\
\hline 1 & TRC & 2,8 & 4,5 & 17,7 & 27,6 \\
\hline 2 & $\begin{array}{l}\text { TRC, } \\
\text { Comstock } \\
\text { [6] }\end{array}$ & 25,7 & 32,2 & 68,9 & 113,1 \\
\hline 3 & PRE & $-1,8$ & $-2,2$ & $-0,5$ & $-0,3$ \\
\hline 4 & $\begin{array}{l}\text { PRE , } \\
\text { Comstock }^{(6)}\end{array}$ & $-1,0$ & $-1,5$ & 1,3 & $-1,0$ \\
\hline
\end{tabular}

TRC meningkat dengan bertambahnya volume refrigeran, hal ini disebabkan oleh meningkatnya tekanan kondensor dan evaporator ${ }^{(6)}$, tekanan kondensor yang tinggi menyebabkan temperatur uap (saturation temperature) juga meningkatnya. Tingginya temperatur uap berpotensi naiknya temperatur subcooling pada kondensor $(\mathrm{TRC})^{(6)}$. Untuk membedakan dengan kegagalan NCG, maka perlu diketahui perubahan tekanan evaporator (PRE). Baik TRC maupun PRE berdasarkan Tabel 8 mampu mendiagnosa kegagalan berlebihnya refrigeran di dalam sistemchiller.

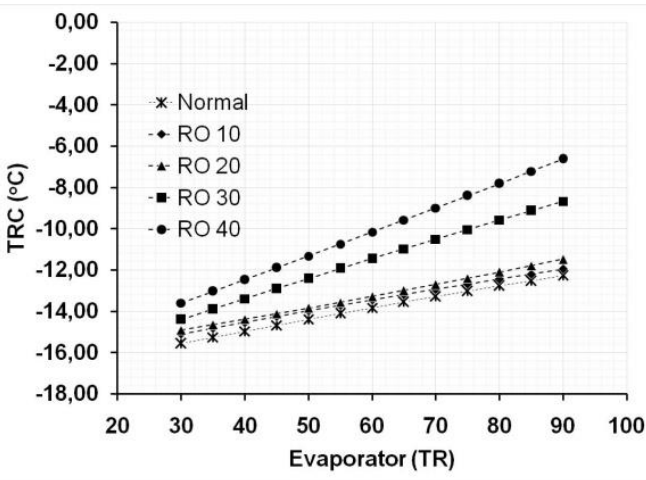

Gambar 6.

Pengaruh kelebihan refrigeran terhadap TRC

Jenis kegagalan berikutnya adalah kapasitas minyak pelumas berlebih, hal ini bisa terjadi ketika penggantian pelumas.Pelumas akan dikosongkan, akan tetapi masih terdapat sisa-sisa pelumas yang menempel atau menempati daerah-daerah yang sulit untuk dikeluarkan. Dengan frekuensi penggantian pelumas berkali-kali, maka volume pelumas didalam kompresor akan bertambah. Minyak pelumas yang berlebihan di dalam sistem kompresor berpengaruh terhadap kinerja chiller. Pada saat pelumas berlebih, maka pelumas akan mengisi ruang kosong yang terdapat pada kompresor dan menggenangi sistem roda gigi secara berlebihan. Hal ini menyebabkan kerugian mekanis yang lebih besar pada kompressor. Kerugian mekanis yang besar ini meningkatkan temperatur pelumas (TO). Oleh karena itu parameter kunci untuk mendiagnosa jenis kegagalan ini adalah TO. Semakin banyak jumlah pelumas didalam kompresor, maka temperatur pelumas semakin tinggi (Tabel 9 dan Gambar 7).Hal yang sama juga diperoleh oleh Comstock yaitu kenaikan TO memiliki kecenderungan yang sama.

Tabel 9.

Deviasi rata-rata suhu pelumas (TO) akibat pelumas yang berlebih

\begin{tabular}{llcccc}
\hline \multirow{2}{*}{ No } & \multirow{2}{*}{$\begin{array}{l}\text { Pelumas } \\
\text { berlebih }\end{array}$} & \begin{tabular}{c} 
Level \\
\cline { 2 - 5 }
\end{tabular} & $\begin{array}{c}\text { Level, } \\
2\end{array}$ & $\begin{array}{c}\text { Level } \\
3\end{array}$ & $\begin{array}{c}\text { Level } \\
4\end{array}$ \\
\hline 1 & TO & 2,9 & 10,1 & 15,1 & 21,3 \\
2 & TO & & & & \\
& Comstock $^{(6)}$ & 2,2 & 6,6 & 10,3 & 16,0 \\
\hline
\end{tabular}




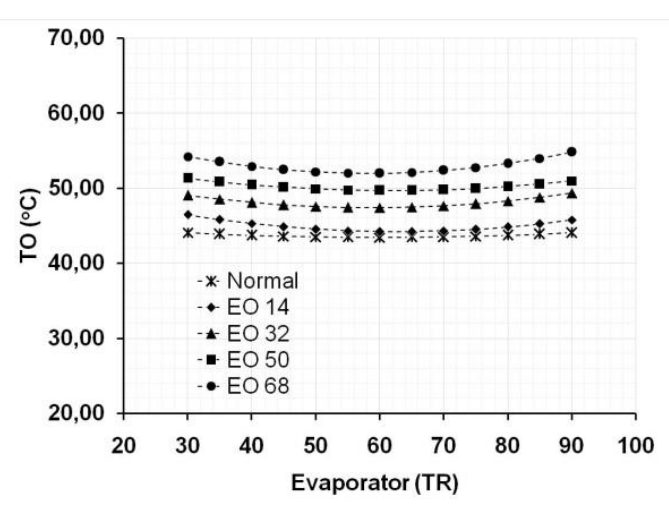

Gambar 7.

Pengaruh pelumas yang berlebihan terhadap TO

Kegagalan berikutnya adalah fouling yang terjadi pada kondensor. Parameter operasi untuk mengidentifikasi fouling pada kondensor adalah temperatur approach kondensor (TCA) seperti terlihat pada Tabel 2. Untuk membedakan dengan kegagalan akibat kelebihan refrigeran dan NCG maka akan digunakan parameter tambahan yaitu TRC. Untuk mengidentifikasi fouling pada kondensor, parameter yang digunakan adalah TCA dan TRC seperti terlihat pada Tabel 10. Untuk TCA, walaupun memiliki persentasiyang berbeda akan tetapi memiliki kecenderungan yang sama dengan yang diperoleh Comstock (Tabel10), yaitu TCA meningkat dengan level kegagalan yang dialami (Gambar9). Sedangkan TRC relatif konstan (Gambar8) baik untuk hasil perhitungan maupun hasil yang diperoleh Comstock (6) (Tabel 10). Oleh karena itu, maka baik TCA dan TRC dapat digunakan untuk mengidentifikasi terjadinya fouling.

Tabel 10.

Deviasi rata-rata parameter operasi terhadap fouling pada kondensor.

\begin{tabular}{|c|c|c|c|c|c|}
\hline \multirow[b]{2}{*}{ No } & \multirow{2}{*}{$\begin{array}{l}\text { Fouling } \\
\text { kondensor }\end{array}$} & \multicolumn{4}{|c|}{ Level, (\%) } \\
\hline & & $\begin{array}{c}\text { Level } \\
1\end{array}$ & $\begin{array}{c}\text { Level } \\
2\end{array}$ & $\begin{array}{c}\text { Level } \\
3\end{array}$ & $\begin{array}{c}\text { Level } \\
4\end{array}$ \\
\hline 1 & TCA & 1,5 & 1,8 & 3,7 & 6,2 \\
\hline 2 & $\begin{array}{l}\text { TCA, } \\
\text { Comstock } \\
\text { [6] }\end{array}$ & 14,8 & 14,9 & 28,1 & 53,8 \\
\hline 3 & TRC & 1,5 & 1,2 & 1,6 & 2,4 \\
\hline 4 & $\begin{array}{l}\text { TRC , } \\
\text { Comstock }^{(6)}\end{array}$ & 4,1 & 0,1 & 4,9 & 1,2 \\
\hline
\end{tabular}

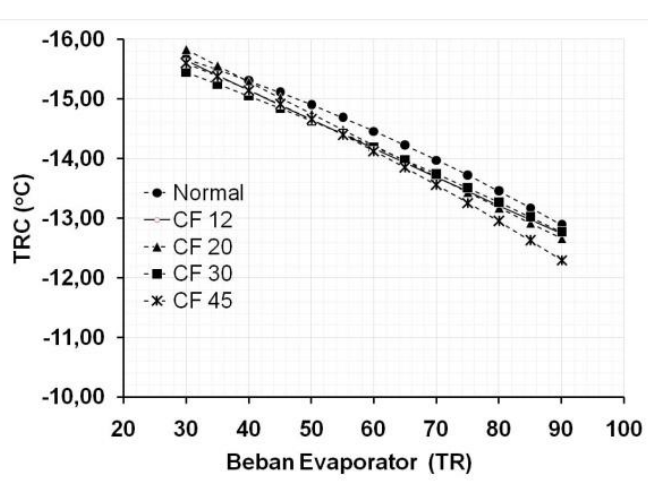

Gambar 8.

Pengaru fouling kondensor terhadap TRC

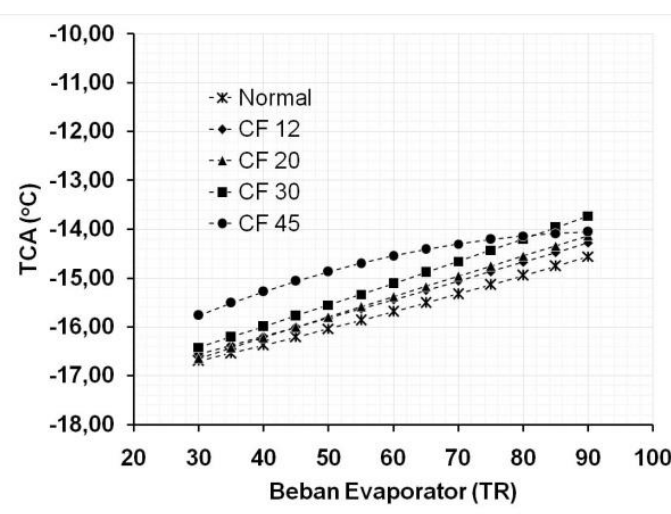

Gambar 9.

Pengaruhfouling kondensor terhadap TCA

Parameter operasi kunci pada kegagalan karena NCG adalah TCA, TRC dan PRE. Besarnya TCA meningkat (Gambar 10) dengan naiknya level kegagalan jika dibandingkan dengan kondisi normal begitu juga TRC (Gambar10) dan PRE (Tabel 11).

Tabel 11

Deviasi rata-rata parameter operasi akibat NCG

\begin{tabular}{|c|c|c|c|c|c|}
\hline \multirow[b]{2}{*}{ No } & \multirow{2}{*}{$\begin{array}{l}\text { Non } \\
\text { condensable }\end{array}$} & \multicolumn{4}{|c|}{ Level, (\%) } \\
\hline & & $\begin{array}{c}\text { Level } \\
1 \\
\end{array}$ & $\begin{array}{l}\text { Level } \\
2 \\
\end{array}$ & $\begin{array}{c}\text { Level } \\
3 \\
\end{array}$ & $\begin{array}{c}\text { Level } \\
4\end{array}$ \\
\hline 1 & TCA & 21,1 & 7,1 & 26,1 & 38,8 \\
\hline 2 & $\begin{array}{l}\text { TCA , } \\
\text { Comstock }^{(6)}\end{array}$ & 134,7 & 166,0 & 195,4 & 315,8 \\
\hline 3 & TRC & 19,7 & 23,8 & 26,9 & 42,3 \\
\hline 4 & $\begin{array}{l}\text { TRC , } \\
\text { Comstock }^{(6)}\end{array}$ & 74,9 & 93,9 & 110,5 & 177,7 \\
\hline 5 & PRE & 0,2 & 4,3 & 4,0 & 13,8 \\
\hline 6 & $\begin{array}{l}\text { PRE, } \\
\text { Comstock }^{(6)}\end{array}$ & 0,9 & 1,1 & 1,6 & 1,0 \\
\hline
\end{tabular}




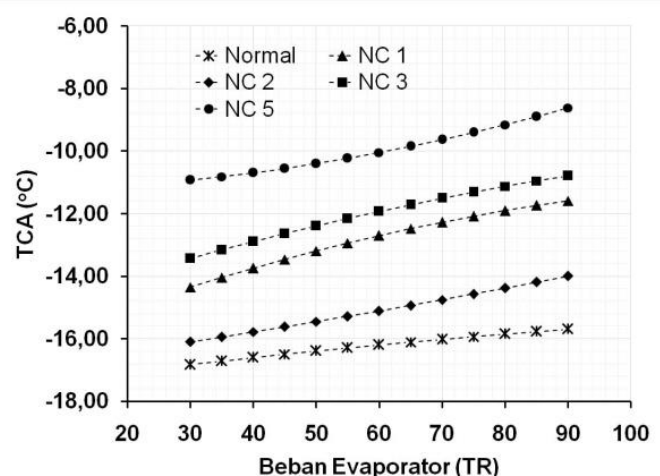

Gambar 10.

Pengaruh NCG terhadap TCA

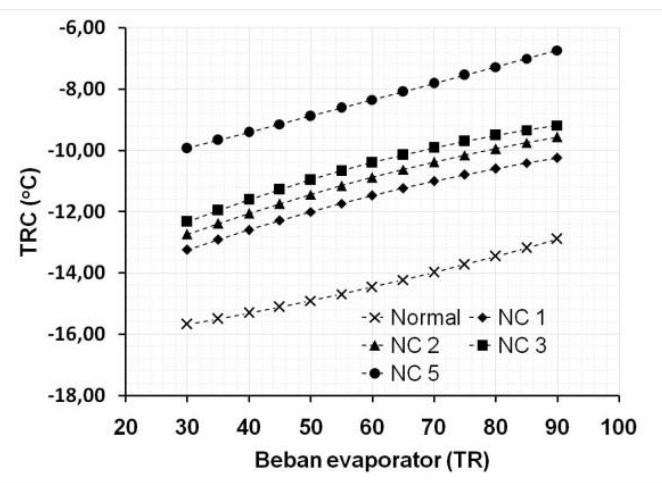

Gambar 11.

Pengaruh NCG terhadap TRC

Jika dibandingkan dengan hasil yang diperoleh Comstock (Tabel 11), hasil dengan regresi satu variabel ini memliki kecenderungan yang sama yaitu meningkatnya parameter-parameter operasi tersebut, walaupun secara persentasi berbeda. Berdasarkan hal ini, ketiga parameter TCA, TRC, dan PRE dapat digunakan untuk mengidentifikasi kegagalan akibat kandungan NCG didalam refrigeran.Kegagalan kerusakan katup ekspansi tidak memiliki level kegagalan 1-4 seperti tujuh jenis kegagalan sebelumnya. Dalam jenis kegagalan ini diambil dua parameter kunci untuk mengidentifikasi kerusakan pada katup ekspansi yaitu TCA dan PRC. Hasil regresi satu variabel (Tabel 12), TCA menurun dengan rusaknya katup ekspansi, hal yang sama diperoleh oleh Comstock (Tabel 12 dan Tabel 2). Sedangkan untuk TRC mengalami kenaikan sedikit (Tabel 12) yang bisa dikatakan parameter tersebut konstan, Comstock juga mendapati seperti terlihat di Tabel 2 dengan simbol titik (parameter konstan) dan Tabel 12.
Tabel 12

Deviasi rata-rata parameter kunci akibat kerusakan katup ekspansi

\begin{tabular}{clc}
\hline No & Katup ekspansi & Parameter $(\%)$ \\
\hline 1 & TCA & $-6,7$ \\
2 & TCA, Comstock [6] & $-10,7$ \\
3 & PRC & 3,1 \\
4 & PRC, Comstock [6] & $-0,4$ \\
\hline
\end{tabular}

\section{PENYEBAB PERBEDAAN PERSENTASE PARAMETER OPERASI}

Deviasi parameter operasi chiller akibat delapan jenis kegagalan ini secara kecenderungan memiliki kesamaan akan tetapi secara nilai absolut (persentasi) memiliki perbedaan. Perbedaan persentasideviasi ini bisa disebabkan oleh beberapa hal:

Pertama adalah perbedaan dalam jenis yang regresi yang digunakan. Comstock menggunakan regresi tiga variabel seperti dalam persamaan (1). Dalam menggambarkan grafik dari persamaan yang didapat dari regresi tiga variabel, Comstock tidak hanya menggunakan beban evaporator sebagai input akan tetapi memasukkan dua jenis variabel tambahan yaitu TEO dan TCl. Sebagai contoh bisa dilihat di Gambar, 1 bahwa perbedaan deviasi parameter TCO$\mathrm{TCl}$ tidak hanyak dipengaruhi oleh beban evaporator akan tetapi juga dipengaruhi oleh nilai TEO dan TCI. Sedangan untuk regresi satu variabel, grafik digambarkan hanya berdasarkan input nilai beban evaporator, sedangkan nilai TEO dan TCl untuk masingmasing titik adalah nilai riil.

Yang kedua adalah rentang data TEO dan TEl aktual diluar yang digunakan Comstock dalam menggambarkan grafik. TEO dan TEI aktual bisa berada di luar batas minimum dan maksimum yang telah ditetapkan oleh Comstock.

Faktor ketiga adalah satuan yang digunakan berbeda. Comstock menggunakan satuan Fahrenheit untuk temperatur, sedangkan penelitian ini menggunakan satuan Celcius. Sebagai contoh kenaikan suhu dari $50^{\circ} \mathrm{C}\left(122^{\circ} \mathrm{F}\right)$ ke $100^{\circ} \mathrm{C}\left(212^{\circ} \mathrm{F}\right)$ adalah sebesar $100 \%$ untuk satuan Celcius, sedangkan untuk satuan Fahrenheit kenaikan yang terjadi hanya $74 \%$. Sehingga perbedaan persentasideviasi tidak dapat dihindarkan dalam membandingkan hasil yang kami peroleh dengan yang didapat oleh Comstock. Kecuali untuk daya kompressor, Comstock menggunakan satuan SI yaitu kW. 
Oleh karena hal itu, maka komparasi yang dilakukan hanya berdasarkan kecenderungan yang terjadi dan bukan berdasarkan persentasideviasi dari parameter operasi kunci. Dan ini merupakan hal biasa ditemui dalam pemeliharaan prediktif atau condition monitoring. Contohnya adalah aplikasi alat analisa vibrasi. Untuk dua alat jenis alat analisa vibrasi biasa memiliki hasil pengukuran yang berbeda dalam nilai absolut tetapi memiliki kecenderunganyang sama untuk keduanya.

\section{KOMPARASI KECENDERUNGAN PARAMETER OPERASI}

Berdasarkan parameter operasi kunci yang dapat digunakan untuk mengidentifikasi kegagalan, akan kita komparasi berdasarkan trend yang ada; naik, turun, dan konstan. Kecenderungan parameter operasi untuk masing-masing jenis kegagalan dan level kegagalan ditabulasi di Tabel 13. Berdasarkan Tabel 13, seluruh parameter operasi untuk masing-masing jenis kegagalan memiliki kecenderungan yang sama, perbedaan minor hanya terdapat pada kebocoran refrigeran dan kelebihan refrigerant (Tabel.13).

Tabel 13.

Kecenderungan parameter operasi

\begin{tabular}{|c|c|c|c|c|c|}
\hline No & $\begin{array}{l}\text { Debit air } \\
\text { kondensor }\end{array}$ & $\begin{array}{c}\text { Level } \\
1\end{array}$ & $\begin{array}{l}\text { Level } \\
2\end{array}$ & $\begin{array}{c}\text { Level } \\
3\end{array}$ & $\begin{array}{c}\text { Level } \\
4\end{array}$ \\
\hline 1 & (TCO-TCI) & & & & \\
\hline 2 & $\begin{array}{l}\text { (TCO-TCl) } \\
\text { Comstock }\end{array}$ & & & & \\
\hline
\end{tabular}

Tabel 13. (lanjutan)

\begin{tabular}{|c|c|c|c|c|c|}
\hline No & $\begin{array}{l}\text { Debit air } \\
\text { evaporator }\end{array}$ & $\begin{array}{c}\text { Level } \\
1 \\
\end{array}$ & $\begin{array}{c}\text { Level } \\
2\end{array}$ & $\begin{array}{c}\text { Level } \\
3\end{array}$ & $\begin{array}{c}\text { Level } \\
4\end{array}$ \\
\hline 1 & (TEI-TEO) & & & & \\
\hline 2 & $\begin{array}{l}\text { (TEI-TEO) } \\
\text { Comstock }\end{array}$ & & & & \\
\hline No & $\begin{array}{l}\text { Kebocoran } \\
\text { refrigerant }\end{array}$ & $\begin{array}{c}\text { Level } \\
1\end{array}$ & $\begin{array}{c}\text { Level } \\
2\end{array}$ & $\begin{array}{c}\text { Level } \\
3\end{array}$ & $\begin{array}{c}\text {-evel } \\
4\end{array}$ \\
\hline 1 & TRC & & & & \\
\hline 2 & $\begin{array}{l}\text { TRC } \\
\text { Comstock }\end{array}$ & & & & \\
\hline No & $\begin{array}{l}\text { Refrigerant } \\
\text { berlebih }\end{array}$ & $\begin{array}{c}\text { Level } \\
1 \\
\end{array}$ & $\begin{array}{c}\text { Level } \\
2\end{array}$ & $\begin{array}{c}\text { Level } \\
3\end{array}$ & $\begin{array}{c}\text { Level } \\
4\end{array}$ \\
\hline 1 & TRC & & & & \\
\hline 2 & $\begin{array}{l}\text { TRC } \\
\text { Comstock }\end{array}$ & & & & \\
\hline 3 & PRE & & & & \\
\hline 4 & $\begin{array}{l}\text { PRE } \\
\text { Comstock }\end{array}$ & & & & \\
\hline
\end{tabular}

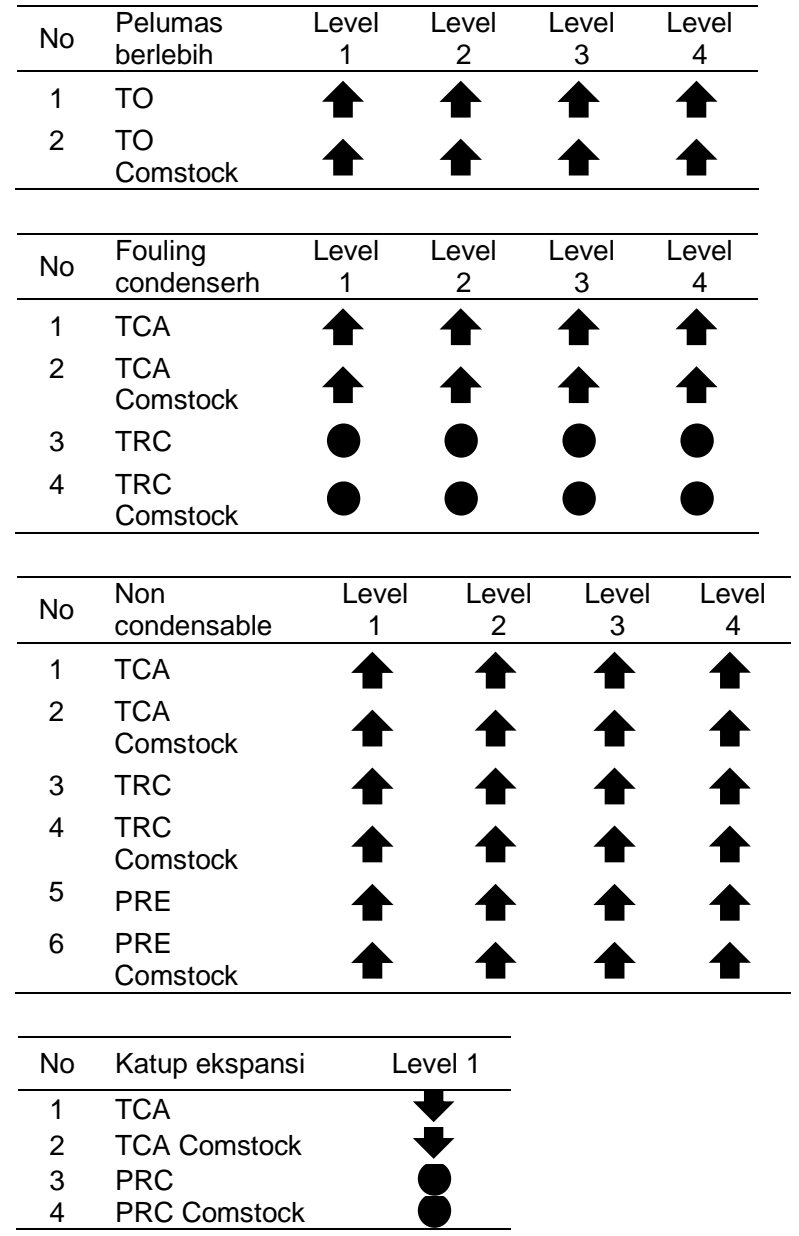

Perbedaan kecenderungan pada level kegagalan 1 untuk kebocoran refrigerant disebabkan oleh salah satu faktor yang dibahas sebelumnya, khususnya nilai TEO, TCO dan TCl yang berada diluar rentang yang ditetapkan oleh Comstock. Hal yang sama juga terjadi pada level kegagalan 3 untuk kegagalan kapasitas refrigerant yang berlebih. Secara rata-rata, kedua jenis kegagalan ini memiliki trend parameter operasi yang sama dengan yang diperoleh Comstock. Oleh karena, bisa dikatakan bahwa trend pada parameter operasi kunci untuk masing-masing kegagalan dapat digunakan dalam membantu mengidentifikasi jenis kegagalan yang terjadi walaupun deviasi yang terjadi antara analisa regresi satu variabel dengan regresi tiga variabel (Comstock) memiliki nilai absolut yang berbeda.Untuk perbandingan pada koefisien korelasi R bisa dilihat pada Tabel 14. Hal ini menunjukkan bahwa regresi tiga variabel memiliki korelasi yang lebih baik dengan regresi satu variabel. Akan tetapi nilai korelasi (R) untuk satu variabel cukup kuat kecuali untuk kerusakan katup ekspansi dimana korelasinya lemah. 
Dari Tabel 13, terdapat 29 skenario kegagalan, dan 27 skenario kegagalan dapat diidentifikasi dengan model regresi satu variable. Dengan kata lain model regresi satu variabel dapat mengidentifikasi $93 \%$ skenario kegagalan yang ada.

Tabel 14

Perbandingan nilai korelasi untuk kegagalan level 1

\begin{tabular}{ccc}
\hline $\begin{array}{c}\text { Parameter } \\
\text { Operasi }\end{array}$ & $\begin{array}{c}\text { Korelasi (R) } \\
\text { Regresi } 1 \\
\text { variabl }\end{array}$ & $\begin{array}{c}\text { Korelasi (R) } \\
\text { Regresi } 3 \\
\text { Varibel }\end{array}$ \\
\hline TCO-TCI & 0,9686 & 0,9996 \\
TEO-TEI & 0,9994 & 0,9999 \\
TRC & 0,9895 & 0,9869 \\
TRC & 0,9742 & 0,9919 \\
TO & 0,7176 & 0,9910 \\
TCA & 0,9772 & 0,9929 \\
TCA & 0,9909 & 0,9948 \\
TCA & 0,4959 & 0,9936 \\
\hline
\end{tabular}

\section{SIMPULAN}

Berdasarkan hasil perbandingan yang diperoleh, perubahan (deviasi) parameter operasi kunci untuk masing-masing jenis dan level kegagalan yang diperoleh dari perhitungan regresi satu variabel memiliki trend yang sama dengan yang diperoleh oleh Comstock (regresi tiga variabel). Dengan kata lain, parameter-parameter kunci dari analisa regresi satu variabel tersebut dapat digunakan untuk mengidentifikasi atau mendiagnosa jenis kegagalan yang sedang terjadi dengan cukup tepat.

\section{DAFTAR PUSTAKA}

1) R. Saidur, M. Hasanuzzaman, T.M.I. Mahlia, N.A. Rahim, H.A. Mohammed.(2011). Chillers energy consumption, energy savings and emission analysis in an institutional buildings. Energy, Volume 36, Issue 8 .

2) Firdaus, Nofirman. Prasetyo, Bambang Teguh. Luciana, Thomas. (2016). Chiller: Performance Deterioration and Maintenance. Energy Engineering, 113:4, 55-80

3) Comstock, MC. Braun, James E. Groll, EA. (2002). A Survey of common faults for chillers. ASHRAE Transaction, 108, pp 819.

4) Mathew C. Comstock. James E. Braun. EA, Groll (2001). The Sensitivity of Chiller Performance to CommonFaults. HVAC\&R Research, 7:3, 263-279.

5) Mathew C. Comstock. James E. Braun. (1999). Experimental data from fault detection and diagnostic studies on a centrifugal chiller. ASHRAE Research project 1043-RP. HL 99-18, Report \#4036-1

6) Mathew C. Comstock. James E. Braun. (1999). Development of analysis tools for the evaluation of faults detection and diagnostics for chillers. ASHRAE Research project 1043-RP. HL 9920,Report \#4036-3

7) Saththasivam, J.,Ng, K.C. (2008). Predictive and diagnostic methods for centrifugal chillers. ASHRAE Transactions 114 PART $1: 282-287$

8) Tassou, SA. Grace, IN. (2005). Fault diagnosis and refrigerant leak detection in vapour compression refrigeration systems. International Journal of Refrigeration, Volume 28, Issue 5

9) R. Saidur et al.(2011). Chillers energy consumption, energy savings and emission analysis in aninstitutional buildings. Energy 36 (2011) 5233-5238 
(halaman ini sengaja dikosongkan) 